
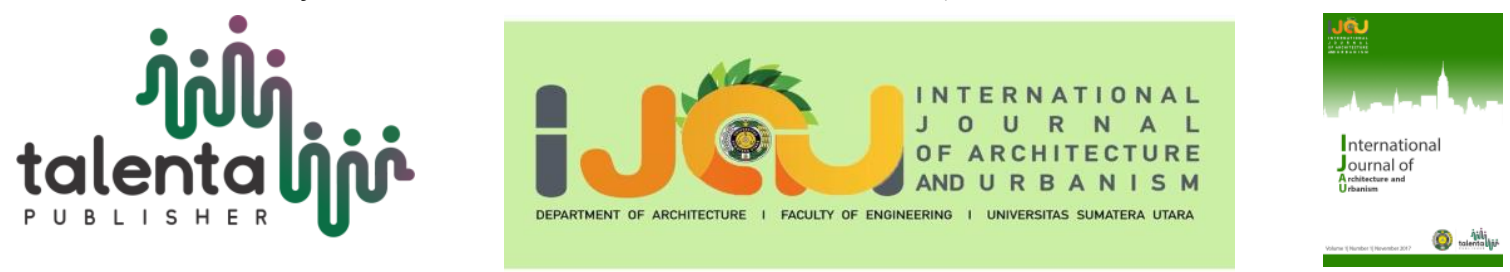

\title{
Comparative Understanding of Traditional Architecture based on Literature Review: Refining the Definition of Traditional Architecture
}

\author{
Hamka $^{1 *}$, Sri Winarni ${ }^{1}$ \\ ${ }^{1}$ Departement of Architecture, Faculty of Civil Engineering and Planning, Institut Teknologi Nasional, \\ Malang, Indonesia
}

\begin{abstract}
Traditional architecture is often a topic of discussion in the literature as well as in academic discussions and the architect's profession. However, sometimes we also encounter differences in understanding due to different points of view and the literature used. Therefore, this paper aims to re-find the definition of traditional architecture by comparing literature review. The research method used is qualitative descriptive analysis method with comparative approach to journal literature reviews. There are 10 national journals and 9 international journals that passed through the selection process and become research samples. The results show that the majority of journals explain that traditional architecture is closely related to the culture of the people in a place that identical to the region or ethnicity. Residential houses as a form of architecture are one of the cultural products of hereditary heritage which are motivated by cultural aspects such as religion, customs, beliefs, philosophies, building process rules, and social aspects to show the social stratification of society through symbols and ornaments. Architectural physical aspects studied in traditional architecture include spatial patterns, structures, materials, main access, space boundaries (walls, roofs, floors), window door openings, orientation, and ornament symbols. In addition, there are also some differences in perception between the contents of the journal in several ways that can be discussed further.
\end{abstract}

Keyword: local wisdom, tradition, traditional architecture

Received 5 September 2021 | Revised 6 October 2021 | Accepted 8 October 2021

\section{Introduction}

The background of the author in conducting research related to the understanding of traditional architecture, because of differences opinion regarding the definition of traditional architecture itself, both orally and writing in several journal articles. This has been a topic of discussion for a long time, everyone has their own point of view and reference. Research related to traditional architectural objects is often viewed from the point of view of ethnography, anthropology, and

*Corresponding author at: Departement of Architecture, Faculty of Civil Engineering and Planning, Institut Teknologi Nasional, Malang, Indonesia

E-mail address: hamka07@lecturer.itn.ac.id

Copyright (C) 2021 Published by Talenta Publisher, 
humanities. Octavia and Prijotomo consider this situation to be worrying because it is a cultural domain and not an architectural material [1].

Traditional in language means hereditary, which is something that is passed down from generation to generation. However, this hereditary understanding needs to be seen from the physical and non-physical aspects of architectural objects. So that, the definition of traditional architecture can be seen from physical and non-physical characteristics based on the results of research that has been carried out by authors related to the topic of traditional architecture. The purpose of this study is to find similarities and differences in understanding the definitions and characteristics of traditional architecture based on a review of the journal literature. Do the writers who raise the topic of traditional architecture have the same understanding or the differences? This research is the first step to find the differences and similarities between traditional, vernacular and archipelago architecture, because the understanding between the three terms also leads often to differences of opinion. To reach this stage, the writer starts by looking for similarities and differences of opinion among journal writers regarding the understanding of traditional architecture topics.

\section{Literature Review}

\section{Comparative Studies}

Comparison according to Indonesian Dictionary is a perbandingan (comparison). In the context of research, comparison is one way that can be done to find answers to fundamentally about cause and effect by analyzing the factors causing the emergence of a phenomenon [2]. Comparative research aims to find similarities and differences about various things such as objects, ideas, people, groups, common views and changes in views [3]. The characteristics of the comparative method has two or more objects under study, each independent and separate has the same pattern or way of working. The object being compared is clear and specific, has a standards and comparison measures [4].

\section{Literature Review}

Literature review is library research or literature studies (literature review, literature research) is a research that examines or critically reviews knowledge, ideas, or findings contained in the body of academic-oriented literature, as well as formulating theoretical and methodological contributions for a specific topic, Cooper [5]. Literature review is a systematic, explicit and reproducible method for identifying, evaluating and synthesizing research results and ideas that have been produced by researchers and practitioners [6]. The journal analysis of the results of this literature review uses the critical appraisal method. Critical appraisal is a journal analysis process that is used as a theoretical basis regarding the differences, similarities and shortcomings of journals that are used through the following stages: (a). Compare: find 
similarities between several literatures, (b). Contrast: finding differences between several literatures, (c). Synthesize : compare the findings, (d). Criticize: give their own opinion based on the sources read., (e). Summarize: make a summary of the findings [7].

\section{Methods}

The research method used is a qualitative method with a comparative research approach through literature review looking for similarities and differences in understanding traditional architecture based on the results of previous studies that have been published in scientific journals. The literature data used in this study are architectural scientific journals with the following criteria (Table 1).

Table 1 Research data criteria

\begin{tabular}{ll}
\hline Criteria & Indicator \\
\hline Topic/Title & Traditional architecture (meaning/features/elements, etc.) \\
\hline Time Period & $\begin{array}{l}\text { Not limited in time, because it will be seen in terms of the } \\
\text { history of the development of the theory itself }\end{array}$ \\
\hline Journal & National and international architecture \\
\hline Data base & $\begin{array}{l}\text { Through the official web journal or architectural scientific } \\
\text { journal portals that have full text }\end{array}$ \\
\hline
\end{tabular}

The selection of literature data to be analyzed is carried out using the snowball sampling technique, which is a technique of taking data sources that are initially small in number, serves to provide initial information that can open the door to obtain wider data from other more valid sources [8]. Journal search procedures through journal databases that meet predetermined criteria (Figure 1).

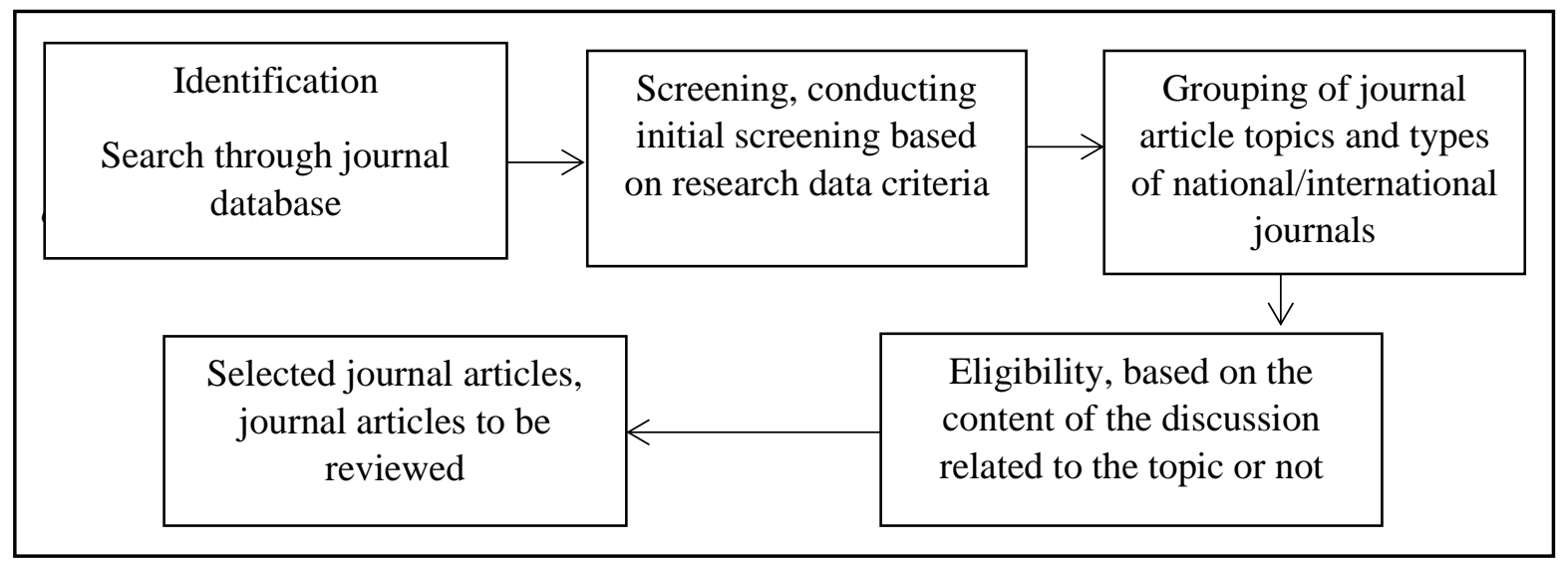

Figure 1 Journal Article Screening Process 
The selected journal articles will be analyzed using the critical appraisal method by finding similarities and differences of opinion between each journal, comparing the findings, providing opinions, and drawing conclusions descriptively.

\section{$4 \quad$ Results and Analysis}

\section{Journal List}

Based on the search results of journals that match the criteria and screening process that have been determined, 10 national journals and 9 international journals that discuss the topic of traditional architecture are selected, the following is a list of journals used as research data (Table 2).

Table 2 Journal List

\begin{tabular}{|c|c|c|c|}
\hline $\begin{array}{l}\text { Journal } \\
\text { Code }\end{array}$ & $\begin{array}{l}\text { Author/ year of } \\
\text { publication }\end{array}$ & Journal & Title \\
\hline & National Journal & & \\
\hline N01 & $\begin{array}{l}\text { Gatot Suharjanto } \\
\text { (2011) }\end{array}$ & $\begin{array}{l}\text { ComTech Vol.2 No. } \\
2\end{array}$ & $\begin{array}{l}\text { Comparing Traditional Architecture } \\
\text { Versus Vernacular Architecture: A Case } \\
\text { Study of Minangkabau and Balinese } \\
\text { Buildings }\end{array}$ \\
\hline N02 & $\begin{array}{l}\text { Febrianto, } \\
\text { Susanti, \& } \\
\text { Istiqoma (2018) } \\
\end{array}$ & $\begin{array}{l}\text { Pawon Vol. II No. } \\
02\end{array}$ & $\begin{array}{l}\text { Reading Traditional and Vernacular } \\
\text { Architectural Spatial Systems With } \\
\text { Ethnographic Research Strategies }\end{array}$ \\
\hline N03 & $\begin{array}{l}\text { Octavia, \& } \\
\text { Hematang } \\
(2017)\end{array}$ & $\begin{array}{l}\text { Mustek Anim Ha } \\
\text { Scientific Journal } \\
\text { Vol. } 6 \text { No. 3, }\end{array}$ & $\begin{array}{l}\text { Adaptation of Forms and Functions of } \\
\text { Traditional Bugis Makassar House } \\
\text { Architecture in Kumbe Village, Merauke }\end{array}$ \\
\hline N04 & Firzal (2018) & $\begin{array}{l}\text { Seminar on } \\
\text { Indonesian } \\
\text { Association of Built } \\
\text { Environmental } \\
\text { Researchers (IPLBI) } \\
2\end{array}$ & $\begin{array}{l}\text { Vernacular and Traditional Conceptions } \\
\text { in the Context of Urban Architecture }\end{array}$ \\
\hline N05 & $\begin{array}{l}\text { Octavia \& } \\
\text { Prijotomo (2018) }\end{array}$ & $\begin{array}{l}\text { Indonesian Journal } \\
\text { of the Built } \\
\text { Environment } 7 \text { (4), }\end{array}$ & $\begin{array}{l}\text { Archipelago Architecture is neither } \\
\text { Traditional Architecture nor Vernacular } \\
\text { Architecture }\end{array}$ \\
\hline N06 & $\begin{array}{l}\text { Sumardiyanto } \\
\text { (2018) }\end{array}$ & $\begin{array}{l}\text { NATIONAL SCAN } \\
\text { SEMINAR }\end{array}$ & $\begin{array}{l}\text { The Future of Traditional Architecture in } \\
\text { the Flow of Modernization }\end{array}$ \\
\hline N07 & $\begin{array}{l}\text { Hatta \& } \\
\text { Sudradjat (2020) }\end{array}$ & $\begin{array}{l}\text { ARTEKS : Journal } \\
\text { of Architectural } \\
\text { Engineering, } \\
\text { Volume 5, Issue 1 }\end{array}$ & $\begin{array}{l}\text { The role of sanro bola in the tradition of } \\
\text { building traditional Bugis houses in } \\
\text { Soppeng. Regenc }\end{array}$ \\
\hline N08 & $\begin{array}{l}\text { Marwati, \& } \\
\text { Andriani (2017) }\end{array}$ & Nature Vol. 4 No. 2 & $\begin{array}{l}\text { Typology of Openings in Bugis } \\
\text { Traditional Houses in Somba Opu Fort } \\
\text { Makassar }\end{array}$ \\
\hline N09 & Rambe (2019) & JAUR, 3 (1) & $\begin{array}{l}\text { Architectural Analysis of Toba Batak } \\
\text { Traditional Houses in Toba Samosir }\end{array}$ \\
\hline
\end{tabular}




\begin{tabular}{|c|c|c|c|}
\hline $\begin{array}{l}\text { Journal } \\
\text { Code }\end{array}$ & $\begin{array}{l}\text { Author/ year of } \\
\text { publication }\end{array}$ & Journal & Title \\
\hline & & & Regency, Balige \\
\hline \multirow[t]{2}{*}{ N10 } & $\begin{array}{l}\text { Santi, \& Syukur } \\
\text { (2010) }\end{array}$ & $\begin{array}{l}\text { Unity Journal of } \\
\text { Architecture } \\
\text { Volume } 1 \text { No. } 1\end{array}$ & $\begin{array}{l}\text { Adaptation of Traditional Balinese } \\
\text { Architecture in Balinese Houses Outside } \\
\text { the Island of Bali }\end{array}$ \\
\hline & \multicolumn{3}{|c|}{ International Journal } \\
\hline I01 & Akande (2020) & $\begin{array}{lr}\text { IAFOR Journal of } \\
\text { Cultural } \quad \text { Studies } \\
\text { Volume } 5 \text { - Issue } 2\end{array}$ & $\begin{array}{l}\text { Manifestations of Orí (Head) in } \\
\text { Traditional Yorùbá Architecture }\end{array}$ \\
\hline $\mathrm{I} 02$ & $\begin{array}{l}\text { Suyoga, } \\
\text { Widyatmika, \& } \\
\text { Juliasih (2020) }\end{array}$ & $\begin{array}{l}\text { International Journal } \\
\text { of Interreligious and } \\
\text { Intercultural Studies } \\
\text { (IJIIS) Volume 3, } \\
\text { Number } 2\end{array}$ & $\begin{array}{l}\text { Bali Traditional Architecture: } \\
\text { Sustainability from the Perspective of } \\
\text { Capital Concept }\end{array}$ \\
\hline $\mathrm{I} 03$ & $\begin{array}{l}\text { Endika \& } \\
\text { Sholihah } \\
\text { (2017) }\end{array}$ & $\begin{array}{l}\text { Journal of } \\
\text { Architectural } \\
\text { Research and Design } \\
\text { Studies Volume 1 } \\
\text { Number 1 }\end{array}$ & $\begin{array}{l}\text { The Identification of Kutai Kartanegara } \\
\text { Traditional Architecture Identity Based } \\
\text { on Comparative Analysis }\end{array}$ \\
\hline I04 & $\begin{array}{l}\text { Ulusoy \& } \\
\text { Kuyrukcu } \\
(2012)\end{array}$ & $\begin{array}{l}\text { Procedia }- \text { Social } \\
\text { and } \quad \text { Behavioral } \\
\text { Sciences } 47\end{array}$ & $\begin{array}{l}\text { The meaning and importance of the } \\
\text { traditional architecture in architecture } \\
\text { education; Gonen winter school model }\end{array}$ \\
\hline $\mathrm{I} 05$ & $\begin{array}{l}\text { Samalavičius \& } \\
\text { Traškinaitė } \\
(2021)\end{array}$ & $\begin{array}{l}\text { Journal of } \\
\text { Architectural Design } \\
\text { and Urbanism, Vol } 3 \\
\text { No } 2\end{array}$ & $\begin{array}{l}\text { Traditional Vernacular } \quad \text { Buildings, } \\
\text { Architectural Heritage and Sustainability }\end{array}$ \\
\hline I06 & $\begin{array}{l}\text { Okoye \& } \\
\text { Ukanwa (2019) }\end{array}$ & $\begin{array}{l}\text { International Journal } \\
\text { of Scientific \& } \\
\text { Engineering } \\
\text { Research Volume } \\
\text { 10, Issue } 11\end{array}$ & $\begin{array}{l}\text { Igbo Traditional Architecture: A Symbol } \\
\text { of Igbo Cultural Identity }\end{array}$ \\
\hline I07 & $\begin{array}{l}\text { Xingyu Ma, } \\
\text { Tianchi Wang } \\
\text { (2020) }\end{array}$ & $\begin{array}{l}\text { Journal of Social } \\
\text { Sciences } 8\end{array}$ & $\begin{array}{l}\text { Research on the Traditional Architecture } \\
\text { Types of Huai' an Canal }\end{array}$ \\
\hline I08 & $\begin{array}{l}\text { Zulkifli } \\
\text { H.Achmad } \\
(2019)\end{array}$ & $\begin{array}{l}\text { LOCAL WISDOM, } \\
11(2)\end{array}$ & $\begin{array}{l}\text { Typology of Bena } \\
\text { Architecture, Flores }\end{array}$ \\
\hline I09 & $\begin{array}{l}\text { Ajaj \& } \\
\text { Pugnaloni } \\
(2014)\end{array}$ & $\begin{array}{l}\text { IACSIT, Vol. 6, No. } \\
4\end{array}$ & $\begin{array}{l}\text { Re-Thinking Traditional Arab } \\
\text { Architecture: A Traditional Approach to } \\
\text { Contemporary Living }\end{array}$ \\
\hline
\end{tabular}

All of the journals listed in Table 2 will be identified, grouped and analyzed based on the focus of the discussion. Finding differences and similarities in the discussion, comparing, criticizing, and making final conclusions. 


\section{Identify the contents of the journal}

The following is the identification of the focus of the selected journal contents Table 3 .

Table 3 Identify the contents of the journal

\section{Journal Results / findings related to traditional architecture}

Code

\begin{tabular}{|c|c|}
\hline & National Journal \\
\hline N01 & $\begin{array}{l}\text { Traditional architecture is identical to vernacular architecture, which is oriented to } \\
\text { the aspects of locality, culture and history of the time span of its existence. } \\
\text { Vernacular architecture is a very specific form of original work with very strong } \\
\text { local content and philosophy and is contextual in nature according to its era, while } \\
\text { traditional architecture is a vernacular masterpiece that has been recognized by } \\
\text { acclamation and handed down from generation to generation for a long and even } \\
\text { very long time. Both come from the same root, if vernacular architecture can be } \\
\text { repeated from generation to generation then it will become traditional } \\
\text { architecture.[9] }\end{array}$ \\
\hline N02 & $\begin{array}{l}\text { Comparing traditional architecture with vernacular from } 5 \text { aspects. The definition } \\
\text { of traditional architecture is seen from these } 5 \text { aspects, such as building designers } \\
\text { (local people, not traditional); basic development (based on non-customary } \\
\text { functions); the concept of development (prioritizing how to regenerate); building } \\
\text { techniques (prioritizing local knowledge or local materials) and building settings } \\
\text { (made based on the environmental setting in which the building was erected). [10] }\end{array}$ \\
\hline N03 & $\begin{array}{l}\text { Based on the literature used in this journal, the author explains the position of } \\
\text { traditional architecture as an element or cultural product of a society or tribe that } \\
\text { grew up in Indonesia such as the Bugis-Makassar Tribe which was used as the } \\
\text { object of research. It is closely related to the values, habits, rules and customs of } \\
\text { the local community which are passed down from generation to generation. The } \\
\text { architectural aspects studied include space, appearance and decoration. [11] }\end{array}$ \\
\hline N04 & $\begin{array}{l}\text { Traditional architecture is architecture with a cultural identity background, local or } \\
\text { local flavor that can be used as a city image identity but can cause cultural side } \\
\text { effects. [12] }\end{array}$ \\
\hline N05 & $\begin{array}{l}\text { The author criticizes traditional architecture so far not from the point of view of } \\
\text { architectural science, but from the perspective of anthropology, geography and } \\
\text { ethnography which is the realm of cultural knowledge, not architectural material. } \\
\text { Then the writer concludes that traditional architecture is knowledge related to } \\
\text { culture and humanities, not architectural knowledge. [1] }\end{array}$ \\
\hline N06 & $\begin{array}{l}\text { In a literature review conducted by the author, it was found that traditional } \\
\text { architecture is part of the study of anthropology and cultural science, architecture } \\
\text { formed by traditions and habits passed down from generation to generation by } \\
\text { community groups from time to time. Its characteristics are not based on theory and } \\
\text { science but are ritual, spiritual, magical and religious, materials are taken from } \\
\text { nature, processed simply without involving many parties. [13] }\end{array}$ \\
\hline N07 & $\begin{array}{l}\text { Based on the study conducted, it can be concluded that traditional architecture is a } \\
\text { product of local culture that is believed to be hereditary. The relationship between } \\
\text { culture and architecture cannot be separated, because architecture is a form of } \\
\text { culture. In the context of the object under study; Bugis traditional houses have a } \\
\text { cultural heritage in the form of philosophy that used as a guide in building a house } \\
\text { through the role of a sanro bola as a leader to choose materials, choose good times } \\
\text { and days, orientate houses, build houses, and apply philosophy. [14] }\end{array}$ \\
\hline N08 & $\begin{array}{l}\text { The typology of ornamentation or opening elements on the facade of replica of } \\
\text { traditional Bugis house in Makassar shows the social status or stratafication of the } \\
\text { owner of the house. So that, traditional architecture is considered include social } \\
\text { aspects of the community. [15] }\end{array}$ \\
\hline N09 & $\begin{array}{l}\text { The architecture of Toba Batak traditional house is the result of the culture of Toba } \\
\text { Batak people in Samosir viewed from an architectural point of view, has a rules }\end{array}$ \\
\hline
\end{tabular}




\begin{tabular}{|c|c|}
\hline Journal & Results / findings related to traditional architecture \\
\hline & $\begin{array}{l}\text { related to the function of space, has a building structure, and ornamentation or } \\
\text { symbols that have a meaning.[16] }\end{array}$ \\
\hline \multirow[t]{2}{*}{ N10 } & $\begin{array}{l}\text { Traditional Balinese architecture is an embodiment of culture based on the } \\
\text { concepts of religion, customs, and art through the philosophy of the Tri Hita and } \\
\text { Tri Angga concepts as a form of balance between humans and the universe and the } \\
\text { natural physical environment. [17] }\end{array}$ \\
\hline & International Journal \\
\hline $\mathrm{I} 01$ & $\begin{array}{l}\text { Arsitektur Yorùbá's traditional architecture is the product of a well-structured } \\
\text { cultural and religious system. Every aspect from the selection of materials, the style } \\
\text { of the building, even the construction system designed with the main consideration } \\
\text { for families, communities, and beliefs. The conclusion is the roof in Yorúa } \\
\text { architecture is a metaphorical object of the original ideology of the local } \\
\text { community. [18] }\end{array}$ \\
\hline $\mathrm{I} 02$ & $\begin{array}{l}\text { The sustainability of traditional Balinese residential architecture in the Balinese era } \\
\text { is being influenced by social stratification in the context of capital ownership, in } \\
\text { Pierre Bourdieu's generative structural theory (economic, cultural, social and } \\
\text { symbolic) which influences the appearance of traditional Balinese houses with } \\
\text { ornaments or without ornaments. [19] }\end{array}$ \\
\hline $\mathrm{I} 03$ & $\begin{array}{l}\text { Identification of traditional Kutai Kertanegara architecture done by comparing the } \\
\text { variables of architectural aspects, namely layout, main access, structure, walls, } \\
\text { roof, ornamentation, and function of the object under study. [20] }\end{array}$ \\
\hline $\mathrm{I} 04$ & $\begin{array}{l}\text { Students conduct field studies to the residential environment of Gonen Village to } \\
\text { recognize the culture and architecture of their unique environment. The houses } \\
\text { studied are interpretations of traditional architecture in Gonen Village. [21] }\end{array}$ \\
\hline $\mathrm{I} 05$ & $\begin{array}{l}\text { There are semantic differences between 'traditional' and 'vernacular' architecture, } \\
\text { but in this article the author uses the terms traditional and vernacular as synonyms. } \\
\text { Because, basically they both come from the same root, which is made by local } \\
\text { residents themselves. This article focuses on vernacular residences in different } \\
\text { parts of Europe: southern Italy and Lithuania which have their own traditions. [22] }\end{array}$ \\
\hline I06 & $\begin{array}{l}\text { Traditional Igbo architecture as a means to promote culture, utilize local building } \\
\text { materials, construction methods and take advantage of the local climate as well as } \\
\text { emphasize aspects of material culture that reflect the beliefs, values and religion of } \\
\text { the Igbo people. [23] }\end{array}$ \\
\hline I07 & $\begin{array}{l}\text { Huai'an canal traditional buildings are divided into three main types based on their } \\
\text { function: residential buildings, public buildings and hydraulic buildings. This } \\
\text { traditional building has become an important physical material for studying canal } \\
\text { culture, urban history, and social development. [24] }\end{array}$ \\
\hline $\mathrm{I} 08$ & $\begin{array}{l}\text { Traditional architecture is the design and development that has been carried out the } \\
\text { same since several generations without significant changes, in order to meet the } \\
\text { space requirements for carrying out certain activities. [25] }\end{array}$ \\
\hline I09 & $\begin{array}{l}\text { Traditional Arabic architectural components can be applied to contemporary } \\
\text { contexts are circulation patterns, orientations, philosophies, blankets and building } \\
\text { materials, building components (walls, openings, roofs), natural circulation, } \\
\text { shading, natural cooling, [26] }\end{array}$ \\
\hline
\end{tabular}

\section{Focus group discussion}

Based on the results of identification of journals, several groups were found based on the focus of the discussion. There were 5 groups of findings from the journals studied, as follows, (Table 4). 
Table 4 Focus Group Discussion

\begin{tabular}{ll}
\hline Journal Code & Focus discussion \\
\hline N01, N03, N04, N05, & Of the 13 journals, they agreed regarding the definition of traditional \\
N06, N07, N09, N10, architecture, that traditional architecture is a cultural product of the \\
I01, I04, I06, I07, I08 & $\begin{array}{l}\text { local community which motivated by various aspects (physical and } \\
\text { non-physical) such as religion, beliefs, customs, philosophies, habits, } \\
\text { rules, building processes, and local materials, ornament or symbol. } \\
\text { These aspects are applied from generation to generation }\end{array}$ \\
\hline N02 & $\begin{array}{l}\text { The contents of this journal provide a different opinion that } \\
\text { traditional architecture is not related to the customs, but only } \\
\text { emphasizes local people, knowledge, and materials }\end{array}$ \\
\hline N08, I02 & $\begin{array}{l}\text { These two journals discuss more about the social aspects of the } \\
\text { community related to the owner's social strata that affect the } \\
\text { appearance of traditional houses }\end{array}$ \\
\hline I03, I09 & $\begin{array}{l}\text { These two journals focus on architectural components or elements } \\
\text { found in traditional architecture, such as layout, main access, } \\
\text { structure, walls, roof, ornamentation, function, circulation pattern, } \\
\text { orientation, philosophy, blankets and building materials. }\end{array}$ \\
\hline I05 & $\begin{array}{l}\text { The author explains that traditional architecture comes from local } \\
\text { residents, it is vernacular, this vernacular house architecture has its } \\
\text { own traditions. }\end{array}$ \\
\hline
\end{tabular}

\section{Discussion of findings}

Based on the results of grouping the focus of the discussion, several things were found as follows;

a. Journals N01, N02, and I05 link traditional architecture with vernacular architecture. Journals N01 and I05 say that traditional and vernacular architecture are different but identical and come from the same root, while journals N02 compare but conclude that they are different.

b. Journal N02 has a different opinion from most opinions regarding the definition of traditional architecture that traditional architecture is not related to culture and customs. Matters related to customs, culture, beliefs and cosmology are aspects of vernacular architecture.

c. The journal N05 explains that traditional architecture is a cultural product and comes from cultural science, ethnography or anthropology, but criticizes that traditional architecture should be viewed from the science of architecture as an architectural material. It needs further explanation from the author related to the architectural point of view in question, because the author says that traditional architecture is knowledge related to culture, but the author of the journal N05 also criticizes if traditional architecture is discussed from the point of view of cultural science. This is different from the journal N07 which says that the 
relationship between culture and architecture cannot be separated, because architecture is a form of culture.

d. The object of research used in each of the journals studied is in the form of a local resident's house, but in journal I07 there are other types that classified as traditional architecture, such as public buildings and hydraulic buildings.

e. The research objects studied in journals whose research locations are in Indonesia, are all residential houses that are identical to regional or ethnic groups in the area such as the Balinese, Minangkabau, Bugis-Makassar, Kutai and Toba Batak tribes. Other locations in Africa, Arabia, the Caspian Coast of Iran, China, and Turkey also show the same thing.

The following is an explanation of the background and process of the emergence of traditional architecture based on the findings of the discussion of the journal literature reviews that have been carried out, to achieve a traditional architecture it must start from a place, a community group, a building is formed from local knowledge, technology, and materials that influenced by it. by the intangible socio-cultural aspects of the community, it continues to be repeated until it goes through a trial and error process and is passed down from generation to generation and able to be maintained and endured for a long time, until it eventually becomes a tradition (Figure 2).

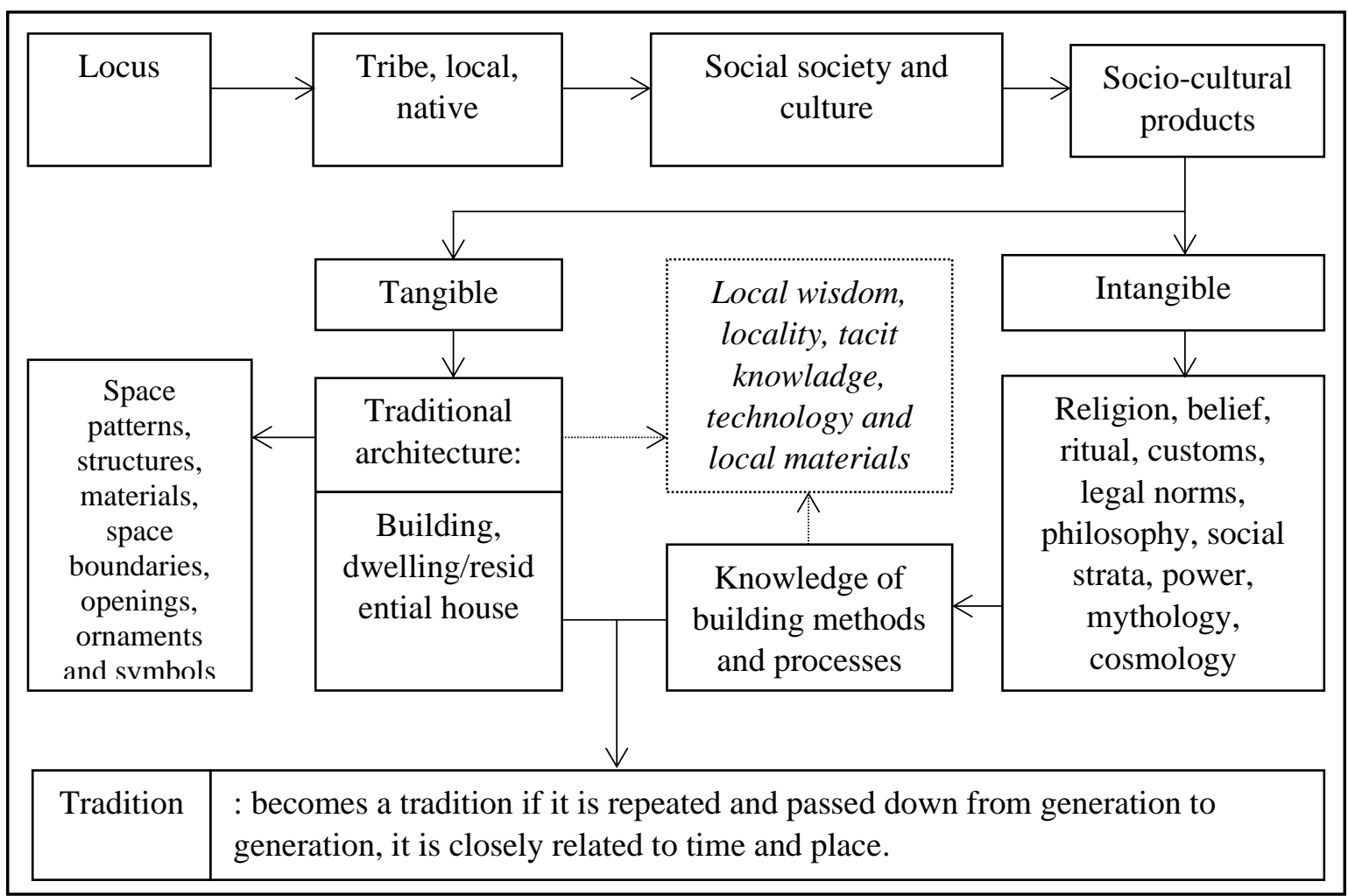

Figure 2 The process of the emergence of traditional architecture

\section{Conclusion}

Based on the results of the reviewing the contents of the journals that have been carried out, it can be concluded that the majority of journals explain that traditional architecture is closely 
related to the culture of the community in a place that is identical to regional or ethnicity. Residential houses as a form of architecture are one of the cultural products of hereditary heritage which are motivated by cultural aspects such as religion, customs, beliefs, philosophies, building process rules, and social aspects to show the social stratification of society through symbols and ornaments. Architectural physical aspects studied in traditional architecture include spatial patterns, structures, materials, main access, space boundaries (walls, roofs, floors), window door openings, orientation, and ornament symbols. The physical aspect of the architecture is closely related to the socio-cultural aspects of the community where the traditional architectural building stands. The differences in perceptions that arise, may be from different perspectives and the literature used, so further discussion is needed to expand the development of traditional architecture itself.

\section{REFERENCES}

[1] L. Octavia and J. Prijotomo, "Arsitektur Nusantara bukan Arsitektur Tradisional maupun Arsitektur Vernakular," J. Lingkung. Binaan Indones., vol. 7, no. 4, pp. 249-253, 2018, doi: 10.32315/jlbi.7.4.249.

[2] Nazir, Moh. Metode Penelitian, 2005. Jakarta: Ghaila Indonesia

[3] Arikunto, Suharsimi. Prosedur Penelitian, Suatu Pendekatan Praktek, Edisi Revisi V. 1997. Jakarta: Rineka Cipta

[4] Jasa Ungguh Muliawan. Metodologi Penelitian Pendidikan dengan Studi Kasus, 2014. Yogyakarta: Gava Media.

[5] Cooper and Schindler. Business research methods. 11th edition-2011. New York: McGraw Hill Companies.

[6] Okoli, C. \& Schabran, K. A Guide to Connducting a Systematic Literature Review of Information System Research. Sprout: Working papers on Information System, 10(26) 2010.

[7] Braun, V., \& Clarke, V. Using thematic analysis in psychology. Research gate, 2006 1-43

[8] Sugiyono. Memahami Penelitian Kualitatif, 2010. Alfabeta: Bandung

[9] G. Suharjanto, "Membandingkan Istilah Arsitektur Tradisional Versus Arsitektur Vernakular: Studi Kasus Bangunan Minangkabau dan Bangunan Bali," ComTech Comput. Math. Eng. Appl., vol. 2, no. 2, p. 592, 2011, doi: 10.21512/comtech.v2i2.2808.

[10] R. Sigit Febrianto, D. Budi Susanti, and M. Istiqoma, "Membaca Sistem Spasial Arsitektur Tradisional Dan Vernakular Dengan Strategi Penelitian Etnografi," Pawon J. Arsit., vol. 2, no. 02, pp. 97-104, 2018, doi: 10.36040/pawon.v2i02.258.

[11] S. Octavia and Y. I. P. Hematang, "Adaptasi Bentuk Dan Fungsi Arsitektur Rumah Tradisional Bugis-Makassar Di Kampung Kumbe, Merauke," Mustek Anim Ha, vol. 6, no. 3, pp. 286-298, 2017, doi: 10.35724/mustek.v6i3.711.

[12] Y. Firzal, "Konsepsi Vernakular dan Tradisional dalam Konteks Arsitektur Perkotaan," no. March 2018, pp. B032-B035, 2018, doi: 10.32315/sem.2.b032.

[13] A. D. A. N. Kota, "Masa depan arsitektur tradisional di tengah arus modernisasi," Semin. Nas. SCAN\#32012 "Sticks Carrots" Reward Punishm. MASA, vol. 3, pp. 241-251, 2012.

[14] A. J. Hatta and I. Sudradjat, "Peran sanro bola dalam tradisi membangun rumah tradisional \{Bugis\} di \{Kabupaten\} \{Soppeng\}," ARTEKS J. Tek. Arsit., vol. 5, no. 1, pp. 63-72, 2020 , https://www.journal.unwira.ac.id/index.php/ARTEKS/article/view/119.

[15] Marwati; Andriani, "TIPOLOGI BUKAAN PADA RUMAH TRADISIONAL BUGIS DI BENTENG SOMBA OPU MAKASSAR Marwati1," Nature, vol. 4, no. 2, pp. 107-120, 2017, doi: DOI: https://doi.org/10.24252/nature.v4i2a3.

[16] Rambe, Analisis Arsitektur pada Rumah Tradisional Batak Toba di Kabupaten Toba Samosir, Balige. JAUR (Journal of Architecture and Urbanism Research) JAUR, 3 (1) Oktober 2019. DOI: 10.31289/jaur.v3i1.2912 
[17] T. K. Di, D. Balinuraga, and L. Selatan, "Adaptasi Arsitektur Tradisional Bali Pada," Unity J. Arsit., vol. 01, no. 01, pp. 312-321, 2018.

[18] A. Akande, "Manifestations of Orí (Head) in Traditional Yorùbá Architecture," IAFOR J. Cult. Stud., vol. 5, no. 2, pp. 5-19, 2020, doi: 10.22492/ijcs.5.2.01.

[19] I. P. G. Suyoga, M. A. A. Widyatmika, and N. K. A. Juliasih, "Bali Traditional Architecture: Sustainability from the Perspective of Capital Concept," Int. J. Interrelig. Intercult. Stud., vol. 3, no. 2, pp. 50-57, 2020, doi: 10.32795/ijiis.vol3.iss2.2020.1090.

[20] A. B. Sholihah and M. Endika, "the Identification of Kutai Kartanegara Traditional Architecture Identity Based on Comparative Analysis," J. Archit. Res. Des. Stud., vol. 1, no. 1, pp. 23-33, 2017, doi: 10.20885/jars.vol1.iss1.art3.

[21] M. Ulusoy and E. Y. Kuyrukcu, "The Meaning and Importance of the Traditional Architecture in Architecture Education; Gönen Winter School Model," Procedia - Soc. Behav. Sci., vol. 47, pp. 2120-2126, 2012, doi: 10.1016/j.sbspro.2012.06.960.

[22] A. Samalavičius and D. Traškinaite, "Traditional Vernacular Buildings, Architectural Heritage and Sustainability," J. Archit. Des. Urban., vol. 3, no. 2, pp. 49-58, 2021, doi: 10.14710/jadu.v3i2.9814.

[23] C. B. Okoye and O. E. Ukanwa, "Igbo Traditional Architecture: A Symbol of Igbo Cultural Identity," Int. J. Sci. Eng. Res., vol. 10, no. 11, pp. 84-88, 2019.

[24] X. Ma and T. Wang, "Research on the Traditional Architecture Types of Huai'an Canal," Open J. Soc. Sci., vol. 08, no. 11, pp. 287-292, 2020, doi: 10.4236/jss.2020.811026.

[25] Z. H. Achmad, "Typology of bena traditional architecture, Flores," Local Wisdom J. Ilm. Kaji. Kearifan Lokal, vol. 11, no. 2, pp. 90-106, 2019, doi: 10.26905/lw.v11i2.2980.

[26] A. Ajaj and F. Pugnaloni, "Re-Thinking Traditional Arab Architecture: A Traditional Approach to Contemporary Living," Int. J. Eng. Technol., vol. 6, no. 4, pp. 286-289, 2014, doi: 10.7763/ijet.2014.v6.714. 